\title{
Basic School Teachers' Knowledge in Fundamental Curriculum Concepts and Curriculum Development Process in Ghana
}

\author{
Alex Tetteh $^{1^{*}} \quad$ Philip Khumi-Agbasa ${ }^{2}$ \\ 1.Department of Social Studies Education, Faculty of Education, Presbyterian University College, Ghana; P. O. \\ Box 393, Akropong Akuapem; Ghana \\ 2.Department of Economics, St. John's Grammar Senior High School, Accra, Ghana; P.O. Box 183, Achimota, \\ Accra, Accra
}

\begin{abstract}
Teachers' direct involvement in the designing phase of curriculum development process has received massive thumbs up over the years in most countries. However, in Ghana, it is at the implementation phase that the teacher is directly involved. Meanwhile, there is impressive theoretical support for direct teacher-involvement in curriculum development, but educationists in Ghana apparently, do not support the practice of this in our country, and the reaction from teachers is unenthusiastic. Some educationists cite inadequate knowledge of teachers in curriculum matters as the reason for which curriculum development should not be left in the hands of the classroom teacher. Thus, this study was conducted to investigate the basic school teachers' knowledge in fundamental curriculum concepts and curriculum development process in Ghana. The study is a descriptive survey. A sample size of 297 out of a population of 1,300 teachers from 59 basic schools in the Ga-West Municipality was used. Data were collected using close-ended questionnaire, analysed quantitatively and results presented in percentages, means and standard deviation tables. The study showed that the basic school teachers were not aware of the curriculum development process in Ghana and did not express deeper understanding of curriculum concepts and terminologies required to play a substantial role in curriculum development. The recommendation is that the teacher-training institutions should beef-up the practical training they give to teachers in terms of curriculum theory and practice to effectively function as designers and implementers of the various curricula.
\end{abstract}

Keywords: Keywords: curriculum design, curriculum development, curriculum implementation

DOI: $10.7176 / \mathrm{JEP} / 10-9-11$

Publication date:March $31^{\text {st }} 2019$

\section{Introduction}

A well-known complaint found in international educational literature is that there are as many definitions of the term curriculum as there are authors. For the purpose of this article, an operational definition employed is that of the American Hilda Taba's definition as a plan for learning... (though too short, it encapsulates what most of the definitions hover around). So, developing the plan for learning is referred to as curriculum designing, or sometimes referred to as curriculum development in its generic sense. This covers the entire spectrum of the creation of curriculum materials. It ranges from initial conceptualization and planning to design and implementation and, finally, to evaluation and revision.

Curriculum development can be centralised, i.e. undertaken at the national level by a legally constituted agency of the central government; or decentralised for every state/region, district, school or even the classroom teacher to perform the function of curriculum design. In U.S.A, Britain and Australia for instance, the curriculum is decentralized. The states, provinces and the schools are empowered to design the curriculum to meet their local needs but in line with the national educational goals. In France and China for example, the curriculum is centralized with independent bodies to oversee the designing of the curriculum (International Bureau of Education, 2011).

The curriculum development system in Ghana is centralised and assumes fidelity in implementation (Kwarteng, 2009). That is, its development is entrusted into the hands of a statutory body called the Curriculum Research and Development Division (CRDD) since 1967; and the curricular product developed is strictly implemented as the framers prescribed. Whether centralised or decentralised, the process of developing the curriculum is similar. Generally, the process usually starts with needs assessment (situational analysis), and then the design stage, the implementation stage, and finally, the evaluation stage. After some time, the process may start all over again depending on the results of the formative and summative evaluations of the programme. This makes the process of curriculum development cyclical.

Over the years, scholars (for example, Ornstein \& Hunkins, 2004; Glickman, 1998; Barth, 1990, among others) have identified limited engagement of teachers, especially, those at the basic school level, in meaningful curriculum decision-making. They identified this as a major flaw in most educational systems and indicated that it has been elemental in the failure of efforts toward effective educational reforms. In Ghana, the teacher's role has always been at the implementation (teaching) phase and the reaction from teachers to convince authorities to involve them in the designing phase has always been unenthusiastic.

Apparently, the educationists are indifferent, or perhaps, are simply not in support of the practice of direct 
teacher-involvement in the designing phase despite the impressive arguments in support by popular scholars such as Ornstein and Hunkins (2004); Glickman (1998); Archbald and Porter (1994);. Fullan (1993); Barth (1990); Giroux (1988); Young (1979); Rugg and Shumaker (1928); Briggs (1926); Bonser (1924); and John Dewey (in his Education for Democracy). Generally, these scholars agree that teachers should participate fully in any revision of a curriculum to such a degree that they would feel a large share of authorship in its changes and of responsibility for carrying out the changes.

More often than not, some educationists cite inadequate knowledge of teachers in curriculum matters as the reason for which curriculum development should not be left in the hands of the classroom teacher. Even, Rugg and Shumaker (1928) recognized this many years ago and suggested that teachers should upgrade their knowledge in curriculum issues to work collaboratively with curriculum specialists to design curriculum materials. Thus, knowledge of basic curriculum principles and theories as well as awareness of the process of curriculum development in a country, region or district is part of the important requirements for full participation in curriculum design. Yet, the question of whether or not, the basic school teacher in Ghana possesses such elementary knowledge still lingers. Here is the case that their actions or inactions, knowledge or ignorance about the curriculum and its development process has direct implications on what is taught and learnt in school. It was therefore expedient to investigate these issues for effective curriculum development and implementation in Ghana. In view of this, the study sought to find out two things, which are, Basic School Teachers' Knowledge in:

1. Fundamental Curriculum Concepts and,

2. the Curriculum Development Process in Ghana.

\section{Teachers' Knowledge in General Curriculum Concepts}

The teacher is the main agent of curriculum implementation (Bennett, 2002). Their knowledge in curriculum theory and practice is key. The teacher's knowledge in curriculum and teaching was considered esoteric until this came under scrutiny when curriculum development became a focus of study. The curriculum was viewed as separate from the work of the teacher as they were increasingly portrayed and perceived as poorly trained and lacking expertise in curriculum matters (Bennett, $2002 \&$ Kliebard, 1995). Kliebard further contended that the change in the social role of the school came with a change in the educational centre of gravity: it shifted from the tangible presence of the teacher to the remote knowledge and values incarnate in the curriculum. As the centre of gravity shifted from the teacher to the curriculum, so too, did the responsibility for the curriculum shift from the teacher to educational administrators and curriculum experts. Thus, curriculum and curriculum development became an administrative responsibility centred in the superintendents (in the case of Ghana it is the CRDD).

The teacher's knowledge and skill in curriculum as well as the question of who should participate in curriculum construction has always been the concern of most educationists. Many writers express remorse concerns about teacher participation because of poor training, inadequate time, and lack of curriculum expertise among teachers in general (Bennett, 2002). Additionally, some writers maintained that teacher participation has had little impact on the quality or the effectiveness of the curriculum (Winter, 2010). These concerns, among others, have been used consistently as reasons for excluding teachers in the designing stage of curriculum development.

Nevertheless, other people are also of the view that teachers have the needed skill and knowledge to take part in curriculum construction and that their participation brings some benefits because teachers could bring the practical perspectives and experiences that are lacking in courses of study developed solely by administrators and curriculum experts. In addition to the benefits that teacher participation could bring to the curriculum development process, teachers themselves benefit by developing a unified and thoroughly progressive point of view qualifying them for definite responsibility in the construction of the course and its intelligent use later (Gress, 2002).

Regardless of the foregoing advantages in teacher-participation in curriculum development, Snell and Swanson (2000) observed lack of excitement on the part of some teachers to participate, the reason being 'absence of sufficient and systematic preparation'. That is, little or no prior preparation is done for teachers to make the task of curriculum development seem personal and worthwhile to them. Snell and Swanson hold that teachers generally have not been trained to recognize their function in the development of the school curriculum. Thus, it should not be surprising that given the chief authors of the curriculum to be the superintendents, the classroom teachers have not been interested in curriculum development for many years. Many teachers, therefore, have considered the curriculum to be a "ready-made document to be furnished by 'the powers that be" (Ross, 2000).

In any case, whatever level teachers participate in curriculum development, they have to bring to the table some level of competence or knowledge even at the implementation level. Erden (2010) argues that if teachers do not comprehend what the curriculum theoretical framework is all about, they will not only fail to be part of the designing phase but also, they would find it challenging to implement the curriculum to meet the designers' intentions successfully. Erden reported that in spite of the differences in curriculum development in different countries, the competencies identified for teacher curriculum development participation are very similar to the skills teachers use in their professional lives. These are professional knowledge, commitment to change and teamwork. 
Teacher professional knowledge involve content knowledge (what they teach), general pedagogical knowledge (how they teach) and pedagogical content knowledge (why they teach what they teach in a certain manner). Teachers' commitment to change is closely linked to the quality of the impact of the change on their students (McCutcheon, 2002). For teachers to appreciate the quality of the in-coming change, they need to first be part of the decision to bring the change into existence. Conversely, Lombard et al. (2010) maintain that the extent of lack of teachers' knowledge in curriculum design is detrimental to their knowledge and understanding of curriculum implementation as well. This is a contributing factor to the poor curriculum alignment in our centralised system. That is, there is usually no agreement among what is proposed in the curriculum, what is taught and what is assessed. This supports the findings by Harber and Mncube (2010) that most teachers are not clear on how curriculum principles are applied.

\section{Curriculum Development Process in Ghana}

The birth of a policy in curriculum development in Ghana could be associated with the formulation of the Accelerated Development Plan for Education in 1951. The implementation of the plan saw for the first time ever, the introduction of syllabuses in the arithmetic and languages (Abosi \& Brookman-Amissah, 1992). By then, the central body responsible for basic school curriculum development, the Ministry of Education, Curricula and Courses situated at Saltpond did not have adequate resources for the development and dissemination of curriculum for all the schools (ibid). After sometime, the role of curriculum development was placed in the hands of a statutory body called the Curriculum Research and Development Division (CRDD).

The CRDD was established on $1^{\text {st }}$ September, 1967 as a subsidiary of the Ministry of Education based on the recommendation of the Mills-Odoi Commission, after the commission recommended that government should take over all schools and manage them under secular principles. The mission of the CRDD was to be an efficient division equipped with resources for the development of curriculum and instructional materials to make education delivery relevant to the human resource needs of the nation. Thus, it designes syllabi for pre-university institutions, writes textbooks and produces other teaching materials, supervises their trial and monitors their implementation through a network of subject organisers/circuit supervisors attached to the district education offices (Adentwi, 2005).

In terms of structure, the Division has five (5) main Units based on its core functions as indicated on their website (www.ges.gov/?g=con-tent/curriculum-research/-and-development-division-crdd). First, Curriculum Planning and Development: this unit plans curricula (and syllabuses) for Basic and Senior High Schools. It also reviews and revises existing ones in line with existing policies and research outcomes. Second, Curriculum Implementation: this unit disseminates curricular information to stakeholders and offers orientation and training to teachers on the effective use of curricula materials. Third, Curriculum Assessment Services: this unit is charged with addressing the peculiar needs of pupils and assesses the attainment of curriculum objectives and also assesses test instruments developed for learners at the pre-tertiary level. This unit is also responsible for the analysis of examination papers and learners' performance levels for placement and remediation.

Fourth, Development and Evaluation of Instructional Materials and ICT in Education: this develops teachers' handbooks and manuals, which guide teachers on how to handle the syllabuses. The production of tele-teaching materials, audio-visual aids and video tapes for demonstrating lessons is placed in the ambit of this unit. It has the responsibility of evaluating textbooks and other educational materials to guarantee quality and enhance teaching and learning. It also provides instructional materials development/library services and promotes effective use of ICT into the curriculum. Finally, Curriculum Research, Monitoring and Evaluation (CRME): this unit conducts research for curriculum review and revision purposes. It conducts regular monitoring and evaluation to collect data on on-going curriculum interventions. Performance indicators for curriculum amendments are also undertaken by this unit.

Curriculum decision-making is a time consuming and complex task that requires substantial depth and breadth of understanding the educational enterprise, including the relationships and influences that drive policy and practice. The systematic curriculum development process used by CRDD has not been documented yet. However, our interaction with the Deputy Director of CRDD showed that Ghana's approach is eclectic in nature [ProceduralDeliberative Approach (see Figure 1)].

The systematic procedure starts with a policy directive from the Government through the Ministry of Education (MoE) or from the National Council for Curriculum and Assessment (NCCA). The directive may be informed by a public outcry (by educationists, stakeholders, pressure groups, a reform committee's recommendation or desire to meet international standards) or by way of fulfilling a political campaign promise. After all considerations with government, the NCCA defines broad-based objectives for the CRDD to take it up from thence. The CRDD rationalizes the set objectives through research and consultations on the recommendations and enlightens government and the NCCA on the curricular implications of the policy. After being clear on the issues, a panel is formed to develop the curriculum..

The panel is usually made up of representatives of the subject associations, the Ghana National Association 
of Teachers (GNAT), subject specialists and, curriculum design experts from the universities are co-opted. Other agencies whose representatives may serve on the subject panels include the National Advisory Committee on Curriculum for Pre-University Education, the West African Examinations Council (WAEC), the Ministry of Employment, Social Welfare, the National Accreditation Board, the National Teacher Training Council (NTTC), the Bureau of Ghana Languages and the Concerned Parents Association of Ghana (Adentwi, 2005). The CRDD conducts research on the new programme and feeds the panel with the information. After this, the curriculum is developed amidst intensive deliberations.

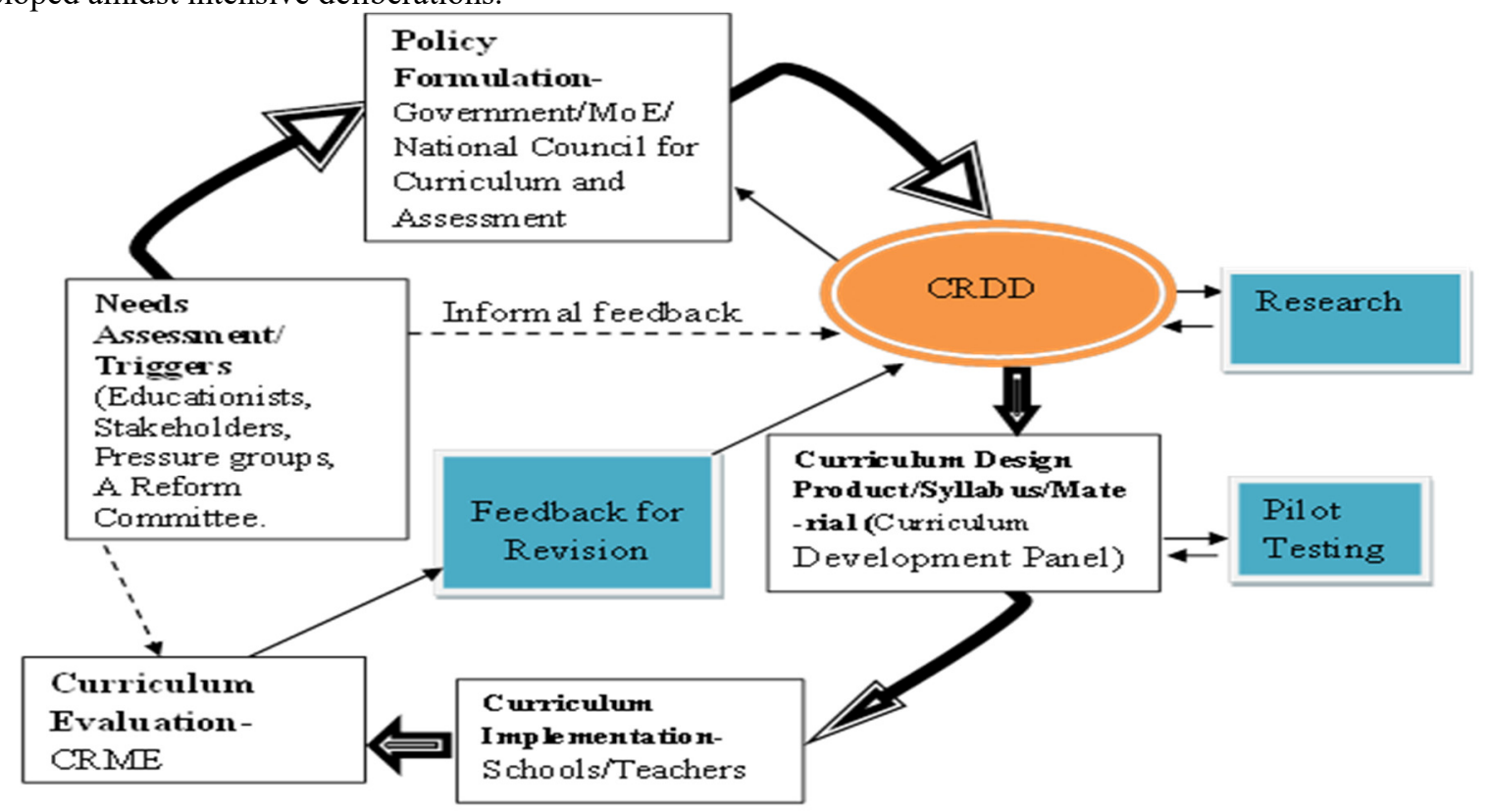

Figure 1: The Curriculum Development Process in Ghana

Source: Researchers' own construct based on inform ation received from the CRDD.

Finally, the tentative curriculum is piloted in selected schools (sample size usually determined by the NCCA). If the results from the pilot test prove valid, the implementation can then be started by first organising training sessions for the teachers on the new programme. The actual developers of the curriculum are not usually the people who offer the training directly to the teachers on the ground (implementers). The training is highly decentralized. Usually, the teachers receive their share of the training through circuit supervisors, head teachers, or selected colleague teachers who have gone through the programme either at the district level or at the Circuit Centre. The major challenge of this kind of training is misinformation or miscommunication due to the long chain of information flow on the new programme.

Most teachers usually complain of lack of training on new programmes before implementation, but Kwarteng (2009) rather found the training sessions to be woefully inadequate. Sometimes, there may be no training at all if it is just a portion of the syllabus that was changed. Whatever the change may be, teachers are to implement the change strictly as given because Ghana's approach to curriculum implementation is the fidelity type. Mostly, new things in the curriculum are only communicated to the District Directors of Education and subject coordinators who are to pass them on; however, it hardly gets to the root in a manner that is required.

In the course of the implementation, the programme is assessed (formative and summative evaluation) and feedback sent to CRDD for consideration and necessary actions to be taken to improve upon the curriculum. This process never ends until the curriculum is innovated or completely replaced by a new one designed out of a recommendation from a committee of distinguished scholars appointed by the government to investigate specific matters relating to education. Their recommendations normally brings radical change that results in a total rethinking and reorganisation of the fundamental elements of the entire curriculum to the extent that major portions of the programme are altered to best solve current challenges or shortcomings in our educational system (i.e. total curriculum change/reform/transformation). A typical example is the 1987 educational reform by the Anfom Committee, which brought about the Junior Secondary School system (Adentwi, 2005). Other notable committees that brought change include the Kwapong Committee (1967), Dzobo Committee (1972), and the AnamuahMensah Committee (2002). In all these, the CRDD had to develop the curriculum to conform to the recommendations of the committee. Sometimes, all that the CRDD is mandated to do is to make slight modifications to certain aspects of the curriculum (i.e. curriculum innovation). This makes the curriculum development a process and circular in nature. 


\section{Methodology}

This study adopted the descriptive survey approach. The descriptive survey "is a research design used to provide a 'picture' of a situation as it naturally happens" (Burns \& Grove, 2003, p. 201). It can be used to justify current practice, attitudes, beliefs, or to make judgments and develop theories (Creswell, 2005). For the purpose of this study, the descriptive survey was used in order to obtain an idea about the teachers' understanding of curriculum theory and in curriculum development process in Ghana. Consequently, the teachers' opinions were surveyed and analysed quantitatively.

Researchers (Marczyk, DeMatteon, \& Festinger, 2005) believe that the influence of extraneous variables on results of descriptive surveys is quite remarkable since it has virtually no control over the variables and the environment of the study. However, in this study, attempts have been made to minimise the limitation(s) even if any. For instance, all members of the target group were literates and therefore, the understanding of the items in the questionnaire was plausible, as very simple language was used to construct them and the respondents virtually asked no question in the course of responding to the items (except for comments they made to express their grievances in their profession).

The population for the study comprised all basic school teachers in the Ga-West Municipality. In all, a total number of 1,300 teachers from 59 basic schools in the Ga-West Municipality comprised the population for the study (GWMA Statistical Office, Amasaman, Accra, 2016). The teachers were of different qualifications and varying experiences in the teaching field. Based on the Krejcie and Morgan's table for selecting sample size (as cited in Sarantakos, 1997), a sample size of 297 teachers was chosen. In order to get an appropriate representation for each school, the quota sampling procedure, which is a non-probability sampling technique, was used. Each school was given $23 \%$ as the quota (see appendix, p. 15). The $23 \%$ is an approximate percentage of 297 of the 1300 teachers in the Municipality. Finally, in each school, teachers who were to be part of the quota were selected using the simple random sampling. The names of the teachers were written and randomly selected by replacement (to avoid bias as alluded by Oso \& Onen, 2008).

Only close-ended questionnaire items were used. The questionnaire had two main parts-Section $\mathbf{A}$ and $\mathbf{B}$. The Section "A" covered the teachers' fundamental knowledge in curriculum concepts and the Section "B" was on teachers' knowledge in the curriculum development process in Ghana. In all, the questionnaire had 16 items. Experts' opinion was sought on the validity of the instrument, and was confirmed to be valid. Additionally, a pilot test was conducted using 30 teachers from two schools in the study area (Amasaman Cluster \& Achiaman Basic Schools) to ascertain the reliability of the instrument using the Cronbach's Alpha. The data were coded into the SPSS and generated a Cronbach's Alpha value of .78, which is good considering that .70 is the cut-off value for being acceptable in terms of that reliability test (Santos, Lippke, \& Pope, 1998).

The questionnaire was administered in February, 2016. Due to the diligent follow-ups made on the administered questionnaire, return rate was good - it was approximately $97 \%$. The SPSS was used to run simple percentage, means and standard deviation tables. These three tools were employed as a way of augmenting each other to reduce the flaws associated with the use of each one alone.

\section{Results}

\subsection{Basic School teachers' Knowledge in Fundamental Curriculum Concepts}

To have an idea about the state of basic school teachers' general knowledge in fundamental curriculum concepts, the teachers in this study were made to respond to eight questions on the subject. Table 1 gives the Percentage distributions (\%), Means (M) and Standard Deviations (STD) of their responses. The statements numbered 1 to 8 in Table 1 are some curricular facts that have been used as a measure of the respondents' level of knowledge in the issue under consideration on a scale of 1 to 5 . Therefore, simply agreeing or strongly agreeing implies that the respondent had fundamental knowledge in curriculum concepts. 
Table 1: Teachers' Knowledge in Fundamental Curriculum Concepts

\begin{tabular}{|c|c|c|c|c|c|c|c|c|}
\hline Statement & $\begin{array}{l}\mathrm{SD} \\
\%\end{array}$ & $\begin{array}{l}\mathrm{D} \\
\%\end{array}$ & $\begin{array}{l}\mathrm{U} \\
\%\end{array}$ & $\begin{array}{l}\mathrm{A} \\
\%\end{array}$ & $\begin{array}{l}\text { SA } \\
\%\end{array}$ & $\begin{array}{l}\text { Total } \\
(\%)\end{array}$ & $\mathrm{M}$ & STD \\
\hline $\begin{array}{l}\text { Curriculum development comprises planning, } \\
\text { implementation and evaluation. }\end{array}$ & 0 & 24 & 21 & 29 & 26 & 100 & 3.58 & 1.12 \\
\hline - Curriculum development is a cyclical process. & 2 & 21 & 54 & 15 & 8 & 100 & 3.12 & 1.37 \\
\hline $\begin{array}{l}\text { - Curriculum development is about gathering logically the } \\
\text { essential things that must be learned in school. }\end{array}$ & 2 & 6 & 24 & 57 & 11 & 100 & 3.70 & .81 \\
\hline $\begin{array}{l}\text { - The development of teaching learning resources (TLRs) } \\
\text { which support and help in the implementation of the } \\
\text { curriculum is a part of development of a curriculum. }\end{array}$ & 1 & 12 & 38 & 26 & 23 & 100 & 3.57 & 1.01 \\
\hline $\begin{array}{l}\text { - Curriculum includes school activities that are academic or } \\
\text { non-academic, vocational or recreational. }\end{array}$ & 4 & 11 & 38 & 28 & 22 & 100 & 3.58 & 99 \\
\hline $\begin{array}{l}\text { - Curriculum includes other unplanned activities which are } \\
\text { educative. }\end{array}$ & 4 & 18 & 50 & 13 & 15 & 100 & 3.48 & .97 \\
\hline - The syllabus is an aspect of the whole curriculum. & 5 & 12 & 12 & 48 & 23 & 100 & 3.74 & 1.08 \\
\hline $\begin{array}{l}\text { - The hidden curriculum consists of unintended things that are } \\
\text { learned consciously or unconsciously by pupils in the school. }\end{array}$ & 18 & 5 & 47 & 9 & 21 & 100 & 3.36 & 1.41 \\
\hline
\end{tabular}

Source: Field survey, Tetteh \& Khumi-Agbasa (2016). $N=297 ; M M=3.52 ; M S T D=1.01$;

Strongly Disagree (1), Disagree (2), Uncertain (3), Agree (4), Strongly Agree (5)

In all, a Mean of Means (MM) of 3.52 which lies closer to the $4^{\text {th }}$ Scale (Agree) than the $3^{\text {rd }}$ Scale (Uncertain) and a Mean of Standard Deviation (MSTD) of 1.01 show that, per the basic school teachers' responses, they had a fair knowledge about fundamental curriculum concepts in general. Their level of knowledge is described as "fair" because, a closer look at the results in Table 1, in terms of the percentages, shows that the knowledge they had was quite limited. For instance, as teachers, $71 \%$ of them agreed altogether that the syllabus is an aspect of the whole curriculum.

In addition, the majority (55\%) of them knew that curriculum development comprises planning, implementation and evaluation, but $54 \%$ of them were uncertain about whether curriculum development is a cyclical process or not $(\mathrm{M}=3.12 ; \mathrm{STD}=1.37)$. They were, likewise, not sure whether curriculum includes other unplanned activities which are educative $(\mathrm{M}=3.48 ; \mathrm{STD}=.97)$. This is confirmed by their uncertainty expressed in responding to the last item in Table 1 that hidden curriculum consists of often unintended things that are learned consciously or unconsciously by pupils in the school.

Furthermore, even though $38 \%$ of the respondents expressed uncertainty that curriculum includes school activities which are academic or non-academic, vocational or recreational, half $(50 \%)$ of them either simply or strongly agreed to this fact. For half of the items (items 1, 4, 5 and 7), you need to add the percentages for agree and strongly agree to obtain majority agreement to each statement except the $3^{\text {rd }}$ statement which, outright majority of $57 \%$ agreed to that (that curriculum development is about gathering logically, the essential things that must be learned in school). It is not the best as teachers that relatively larger percentage (38\%) of them wondered whether the development of teaching-learning resources (TLRs) which support and help in the implementation of the curriculum is part of the development of a curriculum.

The foregoing responses leave much to be desired, as these were the very teachers who went through teacher education for a minimum of three years and have studied Curriculum as a course during their training. The next thing to inquire was whether the respondents knew the process of development that the curriculum goes through in Ghana. The next paragraphs below look at the issue.

\subsection{Basic School Teachers' Awareness of the Curriculum Development Process in Ghana}

With the level of knowledge that teachers generally expressed in Table 1, it was expected that they would express similar kind of knowledge about the process of curriculum development in Ghana. Yet, they expressed uncertainty (see Table 2) about five out of the eight statements that sought their awareness level about the process of curriculum development in Ghana. 
Table 2: Basic School Teachers' Awareness of the Curriculum Development Process in Ghana

\section{SD D U A SA Total}

Statement

$\% \quad \% \quad \% \quad \% \quad \% \quad(\%)$

M STD

- There is a central body that develops curriculum on behalf of the government.

$\begin{array}{llllllll}1 & 4 & 9 & 55 & 31 & \mathbf{1 0 0} & 4.50 & .80\end{array}$

- The members that constitute the panel for developing the curriculum are temporary members.

- Curriculum change, innovation or reform in Ghana is issued in the form of a policy from the government.

- Teacher-involvement in curriculum development process in Ghana is by representation from teacher-associations.

- The curriculum development process in Ghana has a research component.

- The panel's development of the curriculum takes a minimum of three sittings.

- I have seen a document on the curriculum development process in Ghana.

- I know the process for the development of curriculum in Ghana. $\begin{array}{llllllll}4 & 28 & 39 & 21 & 8 & \mathbf{1 0 0} & 3.05 & .99\end{array}$

$\begin{array}{llllllll}2 & 8 & 40 & 31 & 19 & \mathbf{1 0 0} & 3.56 & .97\end{array}$

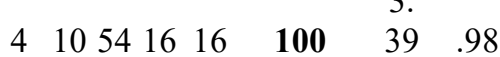

3.

$\begin{array}{llllllll}4 & 5 & 62 & 20 & 9 & \mathbf{1 0 0} & 32 & .87\end{array}$

$\begin{array}{llllllll}5 & 4 & 72 & 15 & 4 & \mathbf{1 0 0} & 3.18 & .74\end{array}$

$\begin{array}{llllllll}53 & 30 & 5 & 4 & 8 & \mathbf{1 0 0} & 2.20 & 1.20\end{array}$

$\begin{array}{llllllll}50 & 35 & 6 & 6 & 3 & \mathbf{1 0 0} & 1.85 & .99\end{array}$

Source: Field survey, Tetteh \& Khumi-Agbasa (2016). N=297; MM=3.13; MSTD=0.94; Strongly Disagree (1), Disagree (2), Uncertain (3), Agree (4), Strongly Agree (5)

Results in Table 2 shows that the basic school teachers lacked adequate knowledge about the process of curriculum development in Ghana. The Mean of Means $(\mathrm{MM}=3.13$; MSTD $=.94)$ evaluation also confirms this uncertainty. Though the majority $(86 \%)$ unanimously indicated that there is a central body that develops curriculum on behalf of the government, they ( $85 \%$ ) unequivocally indicated through their responses that they do not know the process of curriculum development in Ghana $(\mathrm{M}=1.85 ; \mathrm{STD}=.99)$. In the same vein, most of the respondents knew that curriculum change, innovation or reform in Ghana is issued in the form of a policy from the government $(\mathrm{M}=3.56 ; \mathrm{STD}=.97)$ but they were uncertain about whether the curriculum development process in Ghana has a research component or not $(\mathrm{M}=3.32$; $\mathrm{STD}=.87)$. Moreover, they were not sure about how they are involved in the designing phase of the development process.

So, the majority (54\%) of them did not know that teacher-involvement in curriculum development process in Ghana is by representation from the teacher-associations $(\mathrm{M}=3.39$; STD $=.98)$. As teachers, the majority $(83 \%)$ of them had never seen any document on the curriculum development process in Ghana $(\mathrm{M}=2.20 ; \mathrm{STD}=1.20)$. It is not surprising therefore that they did not even know that the members that constitute the panel for developing the curriculum are temporary members $(\mathrm{M}=3.0 ; \mathrm{STD}=.99)$, let alone being sure that the panel's development of the curriculum takes a minimum of three sittings $(\mathrm{M}=3.10$; $\mathrm{STD}=.74)$. All these support the fact that there is lack of literature on the process of curriculum development employed in Ghana.

\section{Discussion}

The basic school teachers' responses to the questionnaire items have given an idea about their knowledge in the fundamental curriculum concepts and the curriculum development process in Ghana. The findings show that the basic schoolteachers had a fair knowledge about fundamental curriculum concepts in general. "Fair knowledge" is not good enough since, as Elliott (1994, p. 50) asserted, "...the quality of children's education depends on the quality of the people teaching them". The teacher needs to be well versed in curricular issues and the processes that led to the development of what they teach in order to teach well. Erden (2010) argues that if teachers do not comprehend what the curriculum theoretical framework is all about, they will not only fail to be part of the designing phase but also, they would find it challenging to implement the curriculum successfully. The literature further shows that quite a number of teachers do not express adequate knowledge in curriculum theory because they are increasingly portrayed and perceived as poorly trained and as such lacking expertise in curriculum matters (Bennett, 2002 \& Kliebard, 1995). Probably, it is because of this inadequate knowledge in curriculum development that has made the call to decentralised curriculum development in Ghana a foil.

Practical knowledge in the process of curriculum development in every country is very essential for the teachers to play their role as effective implementers of the curriculum. However, our teacher educational system in Ghana has poorly offered this kind of knowledge per the kind of responses obtained from the Basic School teachers.For instance, the majority of the Basic School teachers were not aware of the curriculum development process used in Ghana as depicted in Figure 1. With this, the psychological and philosophical bases of the developed curriculum may elude them. Having inadequate idea about the psychological and philosophical basis 
of the development of what they teach also affect their teaching (Erden, 2010)). For instance, having knowledge of the fact that so much research work goes into the designing phase of the curriculum development process gives much confidence and faith in the quality of the curriculum being implemented at the classroom level by the teacher. There is no doubt that successful education also requires that the teaching methods, timing and materials and any other activity conform to the philosophical, psychological, scientific, and sociological (PPSS) intensions of the developers. The teachers' expression of ignorance about the process, conceivably, may not be said to be a mere forgetfulness because, from their responses, a whopping majority of them had never seen any document on the curriculum development process in Ghana before.

Indeed, curriculum development is a cyclical process that never ends until that particular curriculum fizzles out. The cycle include four phases, namely, Phase I (Planning/designing); Phase II (Piloting \& Staff Development); Phase III (Implementation) and Phase IV (Evaluation or Revision). Thus, the curricula that the teachers are currently implementing are still undergoing development in a sense. That is why CRDD requests that all enquiries and comments on the syllabus be addressed to the Director (CRDD), P. O. Box 2739, Accra, Ghana. Based on the formative and summative evaluation results obtained by the CRME unit of CRDD (see Figure 1), the curriculum is revised (improved/reformed or changed). This call by CRDD, perhaps, is mainly to teachers since they are at the centre of implementation. However, the majority of the teachers who were not sure that curriculum development is a cyclical process might not be confident enough or would not even border at all to voice or put into writing their concerns on areas of the curriculum that need amendments from the point of view of their professional practice as implementers.

Lombard, Meyer, Warmich and Wolhutter (2010) maintain that the extent of lack of teachers' awareness in curriculum design is detrimental to their knowledge and understanding of curriculum implementation as well; and this could have an injurious effect on teaching methods and principles adhered to in the classroom. It therefore befalls on the academia and the educational authorities to address this ignorance expressed by the teachers.

Elsewhere in the world (e.g. USA, Australia, among others) where curriculum development is decentralized, the teacher is at the centre of the designing phase of curriculum development and so, has much knowledge of the process involved. Researchers such as Hussain, Dogar, Azeem, and Shakoor (2011) believe that teachers need to be knowledgeable about curriculum and understand the processes by which curricula are developed. This is because when teachers consider curricular issues, for example, they tackle the substantive matter of schooling, which may be expressed in terms of the fundamental questions underpinning the curriculum.

Usually, there tends to be a gap between what is stated in policy and what actually pertains in the schools or fields. Taba (1962) pointed out that education does not consist solely of the mastery of the contents spelt out by the Ministries of Education (in this case, CRDD), but also involves attending to issues defined by local conditions. A teacher who does not know that curriculum includes other unplanned activities that are educative, as portrayed by most teachers in this study, may not see why they should bring inn other educative activities that are relevant to the development of the child, especially, under the current mode of curriculum implementation in Ghana (the fidelity approach).

The education policy statements of many countries emphasise the importance of relating the content of the curriculum and the processes of teaching and learning to the local environment (Taylor \& Mulhall, 1997). For instance, in a school where there are large classes with inadequate learning materials or lack of electricity, it requires an innovative teacher who understands the way the curriculum is to be made flexible (adaptive) to attend to the local issues and still be in line with the general aims of implementing that curriculum. A teacher who really understands the nature of curriculum would appreciate the fact that as far as the official curriculum exist, he/she has a stance to adopt towards the development of the child. It is said that teachers' commitment to change is closely linked to the quality of the impact of the change on their students (McCutcheon, 2002). If we want the basic school curriculum to have so much impact in the lives of pupils, then there is the need to make teachers aware of their role in fixing the parts of the curricula that are usually made impracticable by the existing circumstances in each school. This, however, does not necessarily imply making gross or massive changes in the content of the official curriculum, which might tend to derail the purpose for which that curriculum was designed.

The teachers admitted that curriculum development involves logical gathering of essential things that must be learned in school, however, a handful of them (38\%) wondered whether the development of teaching-learning resources (TLRs) which facilitate the implementation of the curriculum is part of curriculum development or not. This is an indictment on the knowledge of the teachers in curriculum development and supports the view that increasingly portray teachers as poorly trained and lacking expertise in curriculum matters (Bennett, 2002 \& Kliebard, 1995). Such a response from the teachers seems to indicate that they have a very parochial understanding about the preparation of TLMs as a curricular role of curriculum developers and teachers at large. It is the syllabus they know and call "curriculum", and not the other teaching aids like textbooks, teachers' handbooks, flashcards, posters, among others. Therefore, the production of these materials, to them, is not curriculum development per se. If they were certain about this, they would have appreciated the fact that teachers' preparation/production of TLMs is also their curricular role, and by that, they are also curriculum developers at the classroom level. 
In the course of responding to the questionnaire, the teachers posed several questions and made comments which are worth reporting. Some said, "I do not even know where CRDD is, so how can I know what they do practically?" "There has not been any in-service training to inform us about the processes of curriculum development so how can I know the process?" "It is not the teacher's role to design curriculum so why do you want to know whether I know curriculum development process." "CRDD has made us sheer implementers so how would we know what they do over there." From the foregoing comments and questions, it can be understood that the teachers, generally felt they do not play any significant role in the designing phase of curriculum development in Ghana to enable them be abreast with the process. The deduction is that teachers feel alienated from the designing phase of curriculum development but their inadequate knowledge in curricular matters is not really a worry to them. They see their involvement as an illusion (the curricular implications of a teacher who feels alienated from curriculum designing would be very necessary for further investigation).

Based on the foregoing discussions, it can be concluded that basic school teachers do not have deeper understanding of the educational enterprise as a whole and do not demonstrate the depth of curriculum knowledge needed to play a leading role in curriculum development. Therefore, curriculum designing cannot be entrusted into their hands until there is observable improvement in their curricular knowledge and skills.

Secondly, having no knowledge of the process of curriculum development implies that the teachers do not know the actual workload of the process and therefore, might continue to demand a role that is non-existent for them per their curricular knowledge and skills, or fail to appreciate the stage in the process where their role is recognised or important.

\section{Recommendations}

On the bases of the findings of the study and the conclusions arrived at, the following recommendations have been made:

1. The teacher-training institutions should introduce a detailed programme for curriculum studies and as part of teacher professional developments. The teachers themselves should engage in professional development programmes and GES should organize regular in-service training for the teachers to upgrade their knowledge in curriculum theory and practice.

2. The Ministry of Education through GES and CRDD should make teachers aware that implementation of the curriculum is a major part of the process of curriculum development, and therefore, as teachers, they are really at the centre of the process. To this end, teachers should be encouraged to take regular and sustained professional curriculum development activities that are rigorous and reflective in critical pedagogy.

\section{References}

Abosi, O., \& Brookman-Amissah, J. (Ed.). (1992). Introduction to education in Ghana. Accra: Sedco Publishing Limited.

Adentwi, K. I. (2005). Curriculum development: An introduction. Kumasi: Wilas Press Ltd.

Archbald, D. A., \& Porter, A. C. (1994). Curriculum control and teachers' perceptions of autonomy and satisfaction. Educational Evaluation and Policy Analysis, 16(1), 21-39.

Barth, R. (1990). Improving schools from within. San Francisco: Jossey-Bass.

Bennett, R. M. (2002). Teacher participation in curriculum development: A history of the idea and practice, 1890 1940. Georgia, Athens: Georgia State University

Bonser, F. (1924). The elementary school curriculum. New York: The Macmillan Co.

Burns, N., \& Grove, S. K. (2003). Understanding nursing research (3 ${ }^{\text {rd }}$ ed.). Philadelphia: Saunders Company.

Creswell, J. W. (2005). Research design: Qualitative, quantitative, and mixed method approaches ( $2^{\text {nd }}$ ed.). Thousand Oaks, California: Sage publications, Inc.

Elliott, J. (1994). The Teacher's Role in Curriculum Development: An unresolved issue in English attempts at curriculum reform. Journal of Curriculum Studies, 2(1), 43-69.

Erden, E. (2010). Problems that preschool teachers face in the curriculum implementation. Published master's dissertation, Middle East Technical University.

Fullan, M. (1993). Change forces: Probing the depths of education reform. London: The Falmer Press.

Giroux, H. (1988). Teachers, public life, and curriculum reform. Peabody Journal of Education, 69(3), 35-47.

Glickman, C. (1998). Revolutionizing America's schools. San Francisco: Jossey-Bass Publishers.

Gress, J. (Ed.). (2002). Curriculum: Frameworks, criticism and theory. Richmond, CA: McCutchan.

Harber, C., \& Mncube, V. (2010). Chronicling educator practices and experiences in the contexts of democratic schooling and quality education in South Africa. International Journal of Education, 30(6), 614-624.

Hussain, A. Dogar, A. H. Azeem, M., \& Shakoor, A. (2011). Evaluation of Curriculum Development Process. International Journal of Humanities and Social Science, 1 (14), 11-13. Retrieved February 2014, from www.ijhssnet.com

International Bureau of Education (2011). World data on education (4 ${ }^{\text {th }}$ ed.). Geneva: IBE 
Kliebard, H. M. (1995). The rationale revisited. Journal of Curriculum Studies, 27 (1), 81-88.

Kwarteng, T. J. (2009). Status of accounting curriculum: A Concern-based adoption model assessment in Asante and Central Regions. Unpublished master's thesis, University of Cape Coast, Cape Coast.

Lombard, K., Meyer, L., Warmich, P., \& Wolhutter, C. (2010). Outcome-based assessment for South African teacher. Pretoria: Van Schaik.

Marczyk, G. R., DeMatteon, D., \& Festinger, D. (2005). Essentials of research design and methodology. Hoboken, New Jersey: John Wiley \& Sons, Inc.

McCutcheon, G. (2002). Developing the curriculum: Solo and group deliberation. Troy, NY: McGraw-Hill.

Ornstein, A. C., \& Hunkins, F. P. (2004). Curriculum: Foundations, principals and issues (4 ${ }^{\text {th }}$ ed.). Boston: Allyn $\&$ Bacon.

Oso, W. Y., \& Onen, D. O. (2008). Educational research. Kisumu: Lake Publishers.

Ross, A. (2000). Curriculum: Construction and critique. London: Falmer Press.

Rugg, H., \& Shumaker, A. (1928). The child centred school. New York: World Book.

Santos, J. R. A., Lippke, L., \& Pope, P. (1998). Proc factor: A tool for extracting hidden gems from a mountain of variables. Proceedings of the 23rd Annual SAS Users Group International Conference. Cary, NC: SAS Institute Inc.

Sarantakos, S. (1997). Social research ( $2^{\text {nd }}$ ed.). New York: Palgrave.

Snell, J., \& Swanson, J. (2000). The essential knowledge and skills of teacher leaders: A search for a conceptual framework. Paper presented at annual meeting of the American Educational Research Association, New Orleans, Louisiana.

Taba, H. (1962). Curriculum organisation and classroom practice in primary schools: A discussion paper. London: Department for Education.

Taylor, P. and A Mulhall (1997). Contextualising Teaching and Learning in Rural Primary Schools: Using Agricultural Experience, Vols. I \& II. Education Research, Serial no. 20. London: DFID

Winter, H. (2010). Teacher as curriculum leader. International Journal of Teacher Leadership Handler, 3(3), 9698.

Young, J. H. (1979). Teacher participation in curriculum decision making: An organizational dilemma. Curriculum Inquiry, 9(2), 113-127. 